\title{
Students' Opinions about the Distance Education to Art and Design Courses in the Pandemic Process
}

\author{
Sehran Dilmaç ${ }^{1, *}$ \\ ${ }^{1}$ Basic Art Education Department, Art and Design Faculty, Izmir Katip Celebi University, Izmir, Turkey \\ *Correspondence: Basic Art Education Department, Art and Design Faculty, Izmir Katip Celebi University, Izmir, \\ Turkey. Tel: 90-232-329-3535. E-mail: sehran.dilmac@ikcu.edu.tr
}

Received: May 14, 2020

Accepted: June 8, 2020 Online Published: June 20, 2020

doi:10.5430/wje.v10n3p113

URL: https://doi.org/10.5430/wje.v10n3p113

\begin{abstract}
This research was carried out to determine student views on distance education through art and design courses. The study group of the research consists of 45 undergraduate students studying at different faculties of İzmir Katip Çelebi University in Turkey during the spring semester of the 2019-2020 academic year. The focus of the article is to determine the effect of distance education, which is carried out suddenly, on students' perceptions of art lesson. A semi-structured interview technique was performed in this study which covered qualitative data collection techniques. Findings regarding the positive and negative aspects of distance education were obtained from students in the context of their impact on art classes. The results obtained in the research are as follows: The students who take art lessons via distance education are required distance education, also they do not experience any technical difficulties due to the availability of technology, they lost of motivation, they do not meet their socialization needs, and especially some techniques that require practice in art lessons.
\end{abstract}

Keywords: distance education, art education, pandemic process

\section{Introduction}

The use of communication technologies in education has eliminated time and space constraints, and has caused the 21 st century in our knowledge to become the leading actor of radical transformations and changes in the knowledge-based social structure. The fact of education, which is one of the basic dynamics of social life, has been affected by the inclusion of communication technologies in this change and transformation process, and traditional education practices have started to be implemented through new tools and technological environments along with communication technologies. The change and transformation in education, which started with the process of integrating communication technologies into education, also paved the way for the emergence of alternative systems to traditional education practices and further strengthening existing systems such as distance education (Elitaş, 2017).

As a result of the technological developments, communication has no longer been connected to a certain space and time, and its existing borders have caused the education, which is actually a form of communication, to contain new patterns. The integration of communication technologies into education and the fact that information is at the forefront in the information society process we live in has revealed alternative education systems. Distance education is one of these alternative systems. Technological innovations, which constitute the basis and the starting point of the idea of distance education, paved the way for the training of individuals and collective structures at different times and spaces, and a new practice has emerged at any time and anywhere, without the need for physical participation. The space-free feature of distance education has become more and more widespread and has become the basic design logic in today's educational processes.

The first applications of the distance education method that emerged in the 1700 s were letter training. The announcement that shorthand lectures would be given in the Boston Newspaper dated March 20, 1728 is considered among the first examples of distance education (Kaya, 2002: 28). The distance education experience that started with the letter continued over time by gaining new forms and expanding with tools such as telegraph, radio and television. But, undoubtedly, with the emergence of new computer-based communication technologies, distance education practices have gained a new form and started to be used more widely, along with the communication channels and 
styles that dominate the whole society. In many universities, distance education units have been established and with the increase in the number of individuals providing access to communication technologies, the number of individuals participating in distance education has also increased (Bernat \& Frailing, 2015; Toven-Lindsey, Rhoads, \& Lozano, 2015). This is the case in Turkey as well. According to the Higher Education Council of Turkey Statistics, 78 higher education institutions constitute approximately $40 \%$ of the graduate institute in Turkey, are active in distance education programs including undergraduate and associate degree programs. In addition, 3 universities have open education faculties. In the 2017-2018 academic year, 82,457 students enrolled in distance education programs, 1,940,465 students enrolled in open education programs with web-based distance education, and 7,740,502 students in formal education in higher education institutes (COHE, 2018).

"Distance education, which is carried out in environments where teachers and students are separated from each other in terms of time and space" (İşman, 2008: 10), while providing the opportunity for the individual to regain the opportunities he misses in the world of education, also aims to reduce the cost of education and increase the quality of education.

In this context, distance education, which provides an equal opportunity in education for the individual who constitutes an obstacle for his financial situation education and cannot participate in educational activities due to physical or natural conditions, tries to eliminate these obstacles through the means of communication he uses and reaches education to large masses. Distance education makes it possible to reach a wide range of students (Fedyinch, Bradley, $\&$ Bradley, 2015). The pandemic process that the Covid-19 outbreak experienced throughout the world brought the transformation in education back to the agenda by forcing distance education. It is possible to list the reasons for the emergence of distance education as an alternative to the traditional education system in this context as follows. 1) The number of students increases day by day due to the increasing population, 2) The number of qualified teachers does not increase in response to the increasing student population, 3) The educational institutions are not evenly distributed in all regions, 4) Increasing demand for education among adults, 5) Reflection of technological developments in education, 6) The most important capital of knowledge in the process we live in, 7) Maintaining a planned and systematic education understanding in the distance education model, 8) Increasing internet users day by day, 9) Having the same content and structure with formal education, 10) Epidemic diseases (Andrade, 2015). Due to its multidimensional and complex structure, distance education, where speed and quality education is the main goal, contains many goals. Saritaş explains these goals as to eliminate educational limitations, to expand education, to save education from standard conditions, to integrate technology with education and to remove barriers to access information, to contribute to the development of success and individual skills, to provide continuous education and knowledge in line with communication technologies (2009: 139-140). While all these objectives reveal the general profile of distance education, they have had to undergo some transformation from traditional education to achieve the goals and objectives.

It is inevitable to use communication technologies in art education and design education courses, which are an integral part of general education. The acquisition of technology by the individual who makes artistic designs, the ability to do a lot of work in a short time, and to create unique designs and compositions, andeventually cause the artist to be directed to collaborative and collective work from individuality. While aiming, it usually tries to create a civilized society with the same qualities (Zor, 2008: 14)".

Nowadays, studies focusing on factors affecting student participation and strategies for providing student participation in online learning / distance education are increasing (Babelan, Ghhaderi, \& Moenikia, 2011; Ma, Han, Yang, \& Cheng, 2015; Martin \& Bolliger, 2018; O'Lawrence, 2016). For example, the number of articles on distance education (and types of distance education) in the Web of Science database increased from 33 in 2011 to 135 in 2016 (Bağrıç̧ı \& Banyard, 2020). There are different studies in the literature to determine the effect of distance education on student perception (Chaudry \& Rahman, 2010; Dimri \& Chaturvedi, 2009; Yu \& Yang, 2006). Bolliger \& Halupa (2018) shows that distance education has an impact on Student motivation. In their study, Adams and Timmis (2006) found that web-based trainings cause problems in communicating, discussing, and finding solutions for student-student and student-educator. In addition, students emphasized that the time required to come to school can be taken through web-based distance education. In the research conducted by Halter, Kleiner and Hess (2006) on 45 students, the students who did not want to leave their employees and their families stated that they were happy to participate in a web-based training. Bhagati, Wu and Chang (2016) discussed students' perceptions of online learning in four dimensions in their research: instructor characteristics, social presence, instructional design and reliability. As a result of their research, Ward, Peters and Shelley (2010) concluded that students' attitudes towards distance education are positive, and that effective learning in face-to-face education can also be achieved through distance education. In the study of Bağrıaçık (2019) comparing the metaphorical perceptions of students regarding face to face education 
and distance education, it was determined that distance education is not necessary for those who receive face to face education, and because they work in a job for distance education areas. Ünalan (2016) determined that students had positive views about distance education in their research, where they examined student views about graphic lessons given via distance education. Researchers are also trying to find ways to increase participation in distance education environments. In addition, there is an important effort to identify the factors that affect student participation. For example, Carpenter, Reddix and Martin (2016) examined the effects of Web 2.0 tool use on students' participation and retention in coeducation and achieved positive results in increasing participation. Positive findings were also found in studies using some Web 2.0 tools such as Wiki (Snodgrass, 2011) and Facebook (Maisonneuve, Chambe, Lorenzo and Pelaccia, 2015).

As can be seen, different studies in the processes of distance education are discussed. It is an applied field by the nature of art and design education. Beyond the cognitive development of the student, determining students' views for these courses, which are necessary for their affective development, will help in understanding the concept of distance education in depth. Such a review is important for determining student attitudes. In this context, the aim of this study is to determine the views of students who took art and design courses in the distance education environment in the 2019-2020 spring semester. For this purpose, the following research questions are taken into account:

1-What are the difficulties encountered in art and design courses in the distance education process?

2-What are the strengths of the distance education process in art and design lessons?

3-What are the weaknesses of the distance education process in art and design lessons?

4-Is distance education necessary for art and design courses?

5-What different applications can be done in distance education in art and design lessons? Can you give an example?

6- How sufficient is the institution's technological infrastructure to attend to emergency online transition?

\section{Method}

Explanations on the research model, research group, data collection tools, data collection and data analysis are included.

\subsection{Research Method and Model}

This research, which was carried out in order to determine the opinions of university students regarding the distance education process in the context of art and design lessons (Contemporary Art Movements, Basic Design-II, Traditional Marbling Art), was performed by using semi-structured interview technique.

\subsection{Study Group}

The study group of the research consists of 45 undergraduate students studying at different faculties in Izmir Katip Celebi University in the spring semester of the 2019-2020 academic year and who choose art and design courses within the scope of elective courses (Basic Design, Contemporary Art Movements, Traditional Turkish Marbling Art).

\subsection{Data Collection Tool}

Qualitative data were collected by a semi-structured interview form prepared by the researcher and created after the scope validity was reviewed by faculty members. Faculty members examined the questions to make them understandable in terms of language and to reflect the subject clearly. Explanations were made regarding the process of determining the views of the design subjects, what is expected of them, the position of the researcher, the identity of the participants will be kept secret and not used elsewhere. Undergraduate students were asked to report when they are available for the interview. When the students were available, their opinions were taken based on their own permission. During the research process, the participants were asked in which way they would like to be recorded while giving their opinions about the questions. The interviews were recorded in writing as all participants stated that the interviews would express them in written form. The interviews were conducted by the researcher using the web-based video conference system "zoom" program in an environment where pre-service teachers feel comfortable and can express their opinions without hesitation. Interviews were made one to one. The interviews with the participants between 20-25 minutes were recorded in writing and the interview was ended by ensuring that the participant was read at the end of the interview period. According to the content analysis, the data obtained in the interview are divided into codes and categories. Reliability $=$ Agreements $/$ (Agreements + Conflict) reliability formula proposed by Miles and Huberman (1994) was used to ensure reliability among coders. According to this formula, coding reliability was calculated as .89. 
Table 1. Information about Students

\begin{tabular}{|c|c|c|}
\hline Gender & $\mathbf{f}$ & $\%$ \\
\hline Famale & 38 & 84 \\
\hline Male & 7 & 16 \\
\hline Total & 45 & 100 \\
\hline \multicolumn{3}{|l|}{ Faculty/Department } \\
\hline Faculty of Pharmacy & 9 & 20 \\
\hline $\begin{array}{l}\text { Faculty of Social Sciences and Humanities- Department of Media and } \\
\text { Communication }\end{array}$ & 6 & 13.3 \\
\hline $\begin{array}{l}\text { Faculty of Economics and Administrative Sciences - Department of } \\
\text { Political Science and Public Administration }\end{array}$ & 2 & 4.2 \\
\hline $\begin{array}{l}\text { Vocational School of Health Services / Department of Medical Services } \\
\text { and Techniques }\end{array}$ & 5 & 11 \\
\hline Faculty of Health Sciences / Nursing Department & 7 & 16 \\
\hline $\begin{array}{l}\text { Faculty of Health Sciences / Physiotherapy and Rehabilitation } \\
\text { Department. }\end{array}$ & 5 & 11 \\
\hline Faculty of Health Sciences - Department of Nutrition and Dietetics & 3 & 7 \\
\hline Faculty of Medicine & 2 & 4.2 \\
\hline Faculty of Dentistry & 6 & 13.3 \\
\hline Total & 45 & 100 \\
\hline \multicolumn{3}{|l|}{ Class } \\
\hline 1st grades & 40 & 89 \\
\hline 2nd graders & 5 & 11 \\
\hline 3rd graders & - & - \\
\hline 4 th graders & - & - \\
\hline Total & 45 & 100 \\
\hline
\end{tabular}

\subsection{Data Analysis}

In order to analyze the data found after applying the semi-structured interview form, the data encoding is performed regularly, and the data found are classified into categories, and the data is made more meaningful. In this way, it is common to gather and relate data that are in different sections and are semantically related (Yıldırım \& Şimşek, 2003). In this study, by applying data coding technique, a considerable convenience was provided in the arrangement of qualitative data and the data were made meaningful.

\subsection{The Course of the Process}

During the pandemic, art and design lessons were conducted asynchronously. Picciano defines the asynchronous method as "learning status in web-based education occurs at different times (Ünsal, 2007: 8)". In asynchronous education, students enter their website independently of time and space and perform their self-education via computer. The lessons are designed to be suitable for the subjects of art and design units, to benefit from online exercises, support materials, forums where they can have online discussions and social media addresses. For this, online social networks such as facebook, etc. were used. Students shared their work with their classmates on the group page they created on facebook, called "Art and Design Lesson", and made comments on someone's work. In this way, it was tried to ensure that mutual interaction can be established at any time. The material prepared for the course was prepared in an interesting way in accordance with the course content and the level of the student, and the expression was enriched with examples that might attract student's attention. The information contained in the content of material was made simple, and understandable, and it was considered to be suitable for the purpose and scope of the course. Summary information was provided as much as possible.

\section{Results}

Content analysis resulted in six categories. These are as follows; difficulties, strengths, weaknesses, requirement, different applications, technological infrastructure. Table 2 and subsequent explanations are limited to the opinions of undergraduate students regarding the distance learning path processing process of art and design courses. 
Table 2. Opinions of Undergraduate Students Regarding the Difficulties They Encounter in Art and Design Courses in the Distance Education Process

\begin{tabular}{ccl}
\hline Category & f & \multicolumn{1}{c}{ Codes } \\
\hline 15 & Lack of practice regarding distance education \\
& $\left(\mathrm{S}_{3}, \mathrm{~S}_{5}, \mathrm{~S}_{6}, \mathrm{~S}_{7}, \mathrm{~S}_{10}, \mathrm{~S}_{11}, \mathrm{~S}_{18}, \mathrm{~S}_{19}, \mathrm{~S}_{20}, \mathrm{~S}_{21}, \mathrm{~S}_{25}, \mathrm{~S}_{26}, \mathrm{~S}_{27}, \mathrm{~S}_{30}, \mathrm{~S}_{37}\right)$ \\
& 13 & $\begin{array}{l}\text { Inability to fully understand applications } \\
\left(\mathrm{S}_{1}, \mathrm{~S}_{2}, \mathrm{~S}_{4}, \mathrm{~S}_{9}, \mathrm{~S}_{22}, \mathrm{~S}_{28}, \mathrm{~S}_{32}, \mathrm{~S}_{33}, \mathrm{~S}_{35}, \mathrm{~S}_{38}, \mathrm{~S}_{41}\right)\end{array}$ \\
& 11 & Ability to use technology \\
& $\left(\mathrm{S}_{4}, \mathrm{~S}_{8}, \mathrm{~S}_{12}, \mathrm{~S}_{14}, \mathrm{~S}_{15}, \mathrm{~S}_{17}, \mathrm{~S}_{21}, \mathrm{~S}_{23}, \mathrm{~S}_{24}, \mathrm{~S}_{28}, \mathrm{~S}_{32},\right)$ \\
U1 & Uncertainty about what to do on issues \\
Difficulties & $\left(\mathrm{S}_{6}, \mathrm{~S}_{7}, \mathrm{~S}_{9}, \mathrm{~S}_{10}, \mathrm{~S}_{12}, \mathrm{~S}_{13}, \mathrm{~S}_{14}, \mathrm{~S}_{16}, \mathrm{~S}_{20}, \mathrm{~S}_{42}\right)$ \\
& Losing interest $\left(\mathrm{S}_{4}, \mathrm{~S}_{8}, \mathrm{~S}_{17}, \mathrm{~S}_{20}, \mathrm{~S}_{24}, \mathrm{~S}_{28}, \mathrm{~S}_{33}, \mathrm{~S}_{42}, \mathrm{~S}_{45}\right)$ \\
& Not following the lessons $\left(\mathrm{S}_{2}, \mathrm{~S}_{8}, \mathrm{~S}_{13}, \mathrm{~S}_{26}, \mathrm{~S}_{30}, \mathrm{~S}_{32}, \mathrm{~S}_{39}\right)$ \\
& 9 & No difficulty $\left(\mathrm{S}_{29}, \mathrm{~S}_{31}, \mathrm{~S}_{43}, \mathrm{~S}_{44}\right)$ \\
\hline
\end{tabular}

Table 2 shows that the views of undergraduate students regarding the difficulties they encountered in art and design courses in the distance education process are similar. They stated that the transition to distance education was rapid and that this situation was difficult due to the lack of experience to use the system, but that they overcame this difficulty.

From the students, $\mathrm{S}_{10}$ stated that the process was experienced very quickly and that they were caught unprepared. Student $\mathrm{S}_{3}$ stated that he did not know what to do in distance education initially and how to follow the lessons, and then he gained experience as he used this application. Student $S_{12}$ stated that he already had difficulties in using the technology, and that he experienced the negativities of this situation, and tried to solve this problem by getting help from his brother in using technology in the distance education process. Some of the one-to-one quotations of teacher candidates regarding this situation are given below:

$\mathrm{S}_{3}$. Since art and design courses are practice courses, they should be held face to face with the faculty member, and we have difficulties in the distance education process. In addition, the lessons are not as instructive and fun as in the faculty.

$\mathrm{S}_{11}$. In the difficulties we encountered in drawing and painting techniques, our instructors were teaching us directly by practice. Lack of practical application causes deficiency in the function of art and design lessons. In this case, it causes my interest in the lesson to decrease.

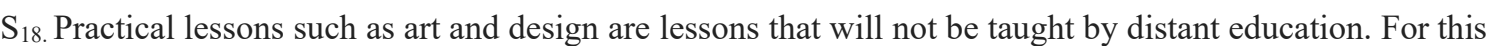
reason, even though we are conceptually informed, we cannot transform our feelings into a tangible product, as we cannot take sufficient action as practice. We, students who take art and design lessons, have difficulty in performing our artistic activities and producing.

It is necessary to prepare the courses to be given through distance education systematically in accordance with the instructional design processes and to create an effective and quality learning environment. Therefore, the design of the teaching process is one of the fundamental subjects of distance education because web-based distance education is different from traditional face-to-face education. First of all, defining a teaching strategy requires understanding what determines success in e-learning (Aparicio, Bacao, \& Oliveira, 2016). Therefore, in the web-based distance education curriculum, students' values, needs and experiences should be of the same or higher quality than the traditional classroom curriculum (Bilgiç \& Tuzun, 2020). Therefore, how consistent a web based course design is with the students 'current values, needs and experiences are important factors in increasing students' academic performance (Islam, 2016). In addition, it will help students to address their needs and give them new experiences and skills, motivate them to reuse these educational services (Alsabawy et al., 2016). When these are realized, it can be thought that some of the difficulties encountered in distance education can be overcome.

$\mathrm{S}_{22}$. We know that application is primarily considered in art and design courses, so distance education is an important challenge for applied courses. Distance learning was a disadvantage for this course since it is a practical lesson. Whether we were drawing or asking questions, we could solve it in a short time with face-to-face communication with our instructor, but distance education extends this period.

$\mathrm{S}_{30}$. Since art and design courses are practical and repetitive, distance learning is not very functional. In addition, since some of the tools that we can use in the workshop are not available in our house, this is a challenge for us. So sometimes I think it's boring when doing my homework. 
In Table 3, the codes related to the strengths of the distance education process in the art and design courses of undergraduate students are given.

Table 3. The Views of Undergraduate Students on the Strengths of the Distance Education Process in Art and Design Courses

\begin{tabular}{|c|c|c|}
\hline Category & $\mathrm{f}$ & Codes \\
\hline \multirow{8}{*}{$\begin{array}{l}\text { A2 } \\
\text { Strengths }\end{array}$} & 22 & Time and space independence \\
\hline & & $\left(\mathrm{S}_{3}, \mathrm{~S}_{4}, \mathrm{~S}_{6}, \mathrm{~S}_{7}, \mathrm{~S}_{9}, \mathrm{~S}_{11}, \mathrm{~S}_{12}, \mathrm{~S}_{14}, \mathrm{~S}_{16}, \mathrm{~S}_{22}, \mathrm{~S}_{22}, \mathrm{~S}_{23}, \mathrm{~S}_{28}, \mathrm{~S}_{33}, \mathrm{~S}_{34}, \mathrm{~S}_{36}, \mathrm{~S}_{39}, \mathrm{~S}_{40}, \mathrm{~S}_{41}, \mathrm{~S}_{43}, \mathrm{~S}_{44}, \mathrm{~S}_{45}\right)$ \\
\hline & 19 & Presenting more examples of practice process \\
\hline & & $\left(\mathrm{S}_{3}, \mathrm{~S}_{5}, \mathrm{~S}_{8}, \mathrm{~S}_{10}, \mathrm{~S}_{14}, \mathrm{~S}_{15}, \mathrm{~S}_{19}, \mathrm{~S}_{21}, \mathrm{~S}_{23}, \mathrm{~S}_{25}, \mathrm{~S}_{26}, \mathrm{~S}_{32}, \mathrm{~S}_{34,} \mathrm{~S}_{35}, \mathrm{~S}_{36}, \mathrm{~S}_{39}, \mathrm{~S}_{40}, \mathrm{~S}_{41}, \mathrm{~S}_{42}\right)$ \\
\hline & 11 & Increased interest in the lesson $\left(\mathrm{S}_{2}, \mathrm{~S}_{4}, \mathrm{~S}_{6}, \mathrm{~S}_{7}, \mathrm{~S}_{9}, \mathrm{~S}_{10}, \mathrm{~S}_{12}, \mathrm{~S}_{13}, \mathrm{~S}_{28}, \mathrm{~S}_{34}, \mathrm{~S}_{37}\right)$ \\
\hline & 8 & $\begin{array}{l}\text { Reduced my spending for the lesson } \\
\left(\mathrm{S}_{5}, \mathrm{~S}_{8}, \mathrm{~S}_{15}, \mathrm{~S}_{22}, \mathrm{~S}_{24}, \mathrm{~S}_{32}, \mathrm{~S}_{34}, \mathrm{~S}_{40}\right)\end{array}$ \\
\hline & 7 & Make things more understandable to everyone $\left(\mathrm{S}_{4}, \mathrm{~S}_{5}, \mathrm{~S}_{14}, \mathrm{~S}_{20}, \mathrm{~S}_{23}, \mathrm{~S}_{39}, \mathrm{~S}_{42}\right)$ \\
\hline & 5 & $\begin{array}{l}\text { Gaining consciousness of responsibility } \\
\left(\mathrm{S}_{7}, \mathrm{~S}_{8}, \mathrm{~S}_{11}, \mathrm{~S}_{26}, \mathrm{~S}_{28}\right)\end{array}$ \\
\hline
\end{tabular}

When Table 3 is examined, it is seen that students express different views on the strengths of the distance education process in art and design courses. According to the student $\mathrm{S}_{3}$, this situation helped him to understand the subject better because he did not have time restrictions and that the subjects were prepared for the lesson in the system.

$\mathrm{S}_{5}$. In our lessons, we often use videos and photos that set an example for our activities. I see that the resources are more frequent and easier to share for such lessons with intense visual material as one of the strengths of the distance education process. Besides, the lack of time and space limitations is one of the strongest aspects of distance education.

The research of Bağrıç̧ı's (2019), which aims to determine the opinions of the students about distance education and face to face education, supports this result. As a result of the Bağrıçı's research, students stated that the fact that distance education is not binding in terms of time and space helps them to take time to deal with other jobs.

$\mathrm{S}_{8}$. Our access to resources has become easier. With the documents uploaded by our teacher, we can access more detailed resources. We have access to more images and videos. We can learn by research. The information content we can reach is high.

Researchers are trying to find ways to increase participation in learning environments in distance education. There is also an important effort to identify the factors that affect student participation. For example, Carpenter, Reddix and Martin (2016) analyzed the effects of Web 2.0 tool use in coeducation on increasing student engagement and interest and achieved positive results in increasing participation.

$\mathrm{S}_{9}$. I think the given videos and assignments have improved our general culture. I also think that doing our homework in a quiet environment at home makes us more productive.

$\mathrm{S}_{12}$. One of the distance education processes is the homework system that replaces midterm examinations. Thanks to this homework system, we read more articles and get a chance to be informed. I think the homework part of distance education is one of the strongest aspects.

$\mathrm{S}_{14}$. Our lecturer, by uploading visuals, texts and resources about the course, clearly states what he wants from us every week. I think the fact that the courses are registered in this way is the strongest aspect of the distance education process.

$\mathrm{S}_{28}$. Even though we have distance education, weekly assignments increase our mental activity during the quarantine process and we have a good time on these gloomy days. I am taking pessimism from my mind by doing my homework during the pandemic period.

$\mathrm{S}_{26}$. I think I am more planned in the distance education process. I'm not going out anymore. So I have less trouble occupying my mind and I can finally weird word my lessons better. I am aware that the obligation to do the homework given in the distance education process on time (the system does not accept the homework given) increases the responsibility towards my classes.

Today, it is almost impossible to imagine a distance education system without an online component. Online learning has also both opportunities and challenges to encourage participation (Tomas, Lasen, Field, \& Skamp, 2015). In online 
learning, students need to manage themselves and participate in their learning, as students do not have enough reinforcements and requests from their instructors and other students (Delen, Liew, \& Wilson, 2014). Student participation and the effects of teachers' attitudes on participation are topics that attract researchers' attention (Ma, Han, Yang, \& Cheng, 2015). In Table 4, the opinions of undergraduate students about the weaknesses of the distance education process in art and design courses are given.

Table 4. The Opinions of Undergraduate Students Regarding the Weaknesses of the Distance Education Process in Art and Design Courses

\begin{tabular}{ccl}
\hline Category & f & Codes \\
\hline 21 & Not being able to practice \\
& $\left(\mathrm{S}_{2}, \mathrm{~S}_{3}, \mathrm{~S}_{5}, \mathrm{~S}_{8}, \mathrm{~S}_{13}, \mathrm{~S}_{14}, \mathrm{~S}_{16}, \mathrm{~S}_{19}, \mathrm{~S}_{21}, \mathrm{~S}_{22}, \mathrm{~S}_{23}, \mathrm{~S}_{24}, \mathrm{~S}_{27}, \mathrm{~S}_{29}, \mathrm{~S}_{32}, \mathrm{~S}_{38}, \mathrm{~S}_{39}, \mathrm{~S}_{40}\right.$, \\
& $\left.\mathrm{S}_{41}, \mathrm{~S}_{42}, \mathrm{~S}_{44},\right)$ \\
& Preventing socialization \\
& $\left(\mathrm{S}_{2}, \mathrm{~S}_{5}, \mathrm{~S}_{6}, \mathrm{~S}_{8}, \mathrm{~S}_{10}, \mathrm{~S}_{16}, \mathrm{~S}_{18}, \mathrm{~S}_{19}, \mathrm{~S}_{20}, \mathrm{~S}_{23}, \mathrm{~S}_{25}, \mathrm{~S}_{28}, \mathrm{~S}_{29}, \mathrm{~S}_{30}, \mathrm{~S}_{37}, \mathrm{~S}_{40}, \mathrm{~S}_{45}\right)$ \\
& Failure to provide instant feedback in applied lessons \\
& $\left(\mathrm{S}_{1}, \mathrm{~S}_{2}, \mathrm{~S}_{9}, \mathrm{~S}_{11}, \mathrm{~S}_{12}, \mathrm{~S}_{13}, \mathrm{~S}_{22}, \mathrm{~S}_{24}, \mathrm{~S}_{25}, \mathrm{~S}_{33}, \mathrm{~S}_{35}, \mathrm{~S}_{39}\right)$ \\
& Requires the ability to use technology \\
A3 & $\left(\mathrm{S}_{4}, \mathrm{~S}_{8}, \mathrm{~S}_{17}, \mathrm{~S}_{20}, \mathrm{~S}_{24}, \mathrm{~S}_{28}, \mathrm{~S}_{33}, \mathrm{~S}_{34}, \mathrm{~S}_{39}\right)$ \\
Leaknesses & Low of motivation \\
& $\left(\mathrm{S}_{31}, \mathrm{~S}_{35}\right)$ \\
&
\end{tabular}

According to Table 4, the vast majority of students such as $S_{2}, S_{3}$ and $S_{5}$ stated that the inability of performing arts and design courses has weaknesses regarding the distance education process, while this applies to all courses, while the student S8 distance learning process was carried out alone while at home. pointed out that this situation, which does not provide the socialization environment in the classroom, is the weakest aspect of the process. On the other hand, $\mathrm{S}_{31}$ stated that distance education cannot motivate them sufficiently and is boring. According to the statements of students, one-to-one quotations are as follows:

$\mathrm{S}_{13}$. Since art and design lessons are practical lessons, they are more productive when they are held in a classroom environment with a faculty member, and this is the only weakness of distance education.

$\mathrm{S}_{17}$. When these practical courses are given by distance education, they cannot be taught sufficiently due to the lack of practical application. I think this is the weakest aspect of the distance education process.

$\mathrm{S}_{16}$. Frankly, it doesn't help me because I can't try what I saw in the video. We can access the theoretical information about the course over the internet or it is delivered by our teachers, but when we do not implement it, one side of the course is missing.

$\mathrm{S}_{8}$. I think that everyone's financial situation is not at a level to have technology. For this reason, there are houses that do not have the necessary tools for the online system, such as internet, computer, telephone or television, although some of us may feel like a joke.

It was determined that students' use of technology is seen as one of the weaknesses of distance education. This situation may have occurred for two reasons. The first is the insufficient financial situation encountered in reaching the technology, and the second is not being able to use the technology sufficiently although there is no financial difficulties in reaching the technology. It was seen that the first of these two views was more present.

$\mathrm{S}_{10}$. In face-to-face education, we were able to work as a group while performing projects related to the course with our friends. In addition to eliminating our shortcomings, we had the opportunity to socialize. I had never realized that this was a need before. As such, we stay away from the motivation of the classroom environment.

Parson stated that the school is a social system and provides an environment where teacher-student and students interact with each other (Baltac1, 2019; Ergün, 1994). School is one of the places that provides socialization. In fact, the socialization of children and young people is becoming the duty of schools completely. Therefore, it can be argued that distance education does not contribute to the socialization of students in this sense or this contribution is limited. In Table 5 opinions about the need for distance education are given. 
Table 5. Opinions about the Need for Distance Education

\begin{tabular}{|c|c|c|}
\hline Category & $\mathrm{f}$ & Codes \\
\hline \multirow{8}{*}{$\begin{array}{l}\text { A4 } \\
\text { Requirement }\end{array}$} & 42 & $\begin{array}{l}\text { It's very requirement } \\
\left(\mathrm{S}_{1}, \mathrm{~S}_{2}, \mathrm{~S}_{3}, \mathrm{~S}_{4}, \mathrm{~S}_{5}, \mathrm{~S}_{6}, \mathrm{~S}_{7}, \mathrm{~S}_{8}, \mathrm{~S}_{9}, \mathrm{~S}_{10}, \mathrm{~S}_{11}, \mathrm{~S}_{12}, \mathrm{~S}_{13}, \mathrm{~S}_{14}, \mathrm{~S}_{15},\right. \\
\mathrm{S}_{16}, \mathrm{~S}_{17}, \mathrm{~S}_{18} \mathrm{~S}_{19}, \mathrm{~S}_{20}, \mathrm{~S}_{21}, \mathrm{~S}_{22}, \mathrm{~S}_{23}, \mathrm{~S}_{24}, \mathrm{~S}_{25}, \mathrm{~S}_{26}, \mathrm{~S}_{27}, \mathrm{~S}_{28}, \mathrm{~S}_{29}, \mathrm{~S}_{30}, \mathrm{~S}_{32}, \mathrm{~S}_{33}, \mathrm{~S}_{34}, \mathrm{~S}_{36}, \quad \mathrm{~S}_{37}, \mathrm{~S}_{38}, \mathrm{~S}_{39}, \\
\left.\mathrm{~S}_{40}, \mathrm{~S}_{41}, \mathrm{~S}_{42}, \mathrm{~S}_{43}, \mathrm{~S}_{45}\right)\end{array}$ \\
\hline & 27 & Access to education $\quad\left(\mathrm{S}_{1}, \mathrm{~S}_{2}, \mathrm{~S}_{4}, \mathrm{~S}_{5}, \mathrm{~S}_{7}, \mathrm{~S}_{8}, \mathrm{~S}_{9}, \mathrm{~S}_{12}, \mathrm{~S}_{14}, \mathrm{~S}_{15}, \mathrm{~S}_{17}, \mathrm{~S}_{21}, \mathrm{~S}_{23}, \mathrm{~S}_{24}\right.$, \\
\hline & & $\left.\mathrm{S}_{28}, \mathrm{~S}_{32}, \mathrm{~S}_{33}, \mathrm{~S}_{34}, \mathrm{~S}_{35}, \mathrm{~S}_{36}, \mathrm{~S}_{38}, \mathrm{~S}_{39}, \mathrm{~S}_{40} \mathrm{~S}_{41}, \mathrm{~S}_{42}, \mathrm{~S}_{43}, \mathrm{~S}_{44}\right)$ \\
\hline & 18 & $\begin{array}{l}\text { Technological necessity } \\
\left(\mathrm{S}_{1}, \mathrm{~S}_{2}, \mathrm{~S}_{6}, \mathrm{~S}_{7}, \mathrm{~S}_{11}, \mathrm{~S}_{12}, \mathrm{~S}_{13}, \mathrm{~S}_{15}, \mathrm{~S}_{17}, \mathrm{~S}_{18}, \mathrm{~S}_{19}, \mathrm{~S}_{23}, \mathrm{~S}_{27}, \mathrm{~S}_{31}, \mathrm{~S}_{37}, \mathrm{~S}_{38}, \mathrm{~S}_{39}, \mathrm{~S}_{40}\right)\end{array}$ \\
\hline & 14 & Low cost in education $\left(\mathrm{S}_{2}, \mathrm{~S}_{3}, \mathrm{~S}_{5}, \mathrm{~S}_{11}, \mathrm{~S}_{18}, \mathrm{~S}_{21}, \mathrm{~S}_{27}, \mathrm{~S}_{33} \mathrm{~S}_{34,} \mathrm{~S}_{35}, \mathrm{~S}_{39}, \mathrm{~S}_{40} \mathrm{~S}_{41}, \mathrm{~S}_{48}\right)$ \\
\hline & 7 & $\begin{array}{l}\text { Taking responsibility } \\
\left(\mathrm{S}_{2}, \mathrm{~S}_{7}, \mathrm{~S}_{15}, \mathrm{~S}_{16}, \mathrm{~S}_{18}, \mathrm{~S}_{27}, \mathrm{~S}_{30}\right)\end{array}$ \\
\hline & 6 & $\begin{array}{l}\text { Equality in education } \\
\left(\mathrm{S}_{6}, \mathrm{~S}_{23}, \mathrm{~S}_{37}, \mathrm{~S}_{38}, \mathrm{~S}_{41}, \mathrm{~S}_{44}\right)\end{array}$ \\
\hline & 3 & It's not requirement $\left(\mathrm{S}_{31}, \mathrm{~S}_{35}, \mathrm{~S}_{44}\right)$ \\
\hline
\end{tabular}

According to Table 5, it is seen that undergraduate students think that distance education is very necessary. While examining the important aspects, student $S_{1}$ allows all students to access education, $S_{2}$ technology advances make it necessary to use in education, $S_{11}$ especially decreases the cost of digital resources in education, increases student $S_{18}$ responsibilities, and $S_{28}$ on the other hand, stated that it provides equality to education because it enables students of different levels to access information whenever they want.

$\mathrm{S}_{6}$. Is necessary. But I am of the opinion that face-to-face education is more useful for practical lessons.

$\mathrm{S}_{14}$. We can reach the lessons whenever and wherever we want. I have seen that more resources are offered in distance education than in face-to-face education. I have a chance to repeat the issues that this situation provides great convenience and not understand.

$\mathrm{S}_{21}$. We had to get the material again, especially when we made a mistake in the practical work we did in art classes. In distance education, we make less mistakes and spend less money because we follow the production processes that our teacher gradually explained by watching videos on the subject while we practice. Since we work at home, I think that working in a comfortable environment affects this situation.

$\mathrm{S}_{31}$. I don't think it's necessary. First of all, it is necessary to consider the working areas of students. Is it possible to give all lessons by distance education? No it is not. If there is no interaction or exchange of information between the instructor and students, learning is not successful and teaching is not carried out. Distance education has never been useful in art and design teaching, as practice in such lessons is very important.

Y1lmaz and Erdem (2018) achieved a similar result in foreign language education according to the results of the research they aimed to determine the views of the lecturers who are teaching in distance education programs. According to the results of this research, they stated that there were some difficulties in foreign language teaching, even in face-to-face education, and this situation increased in the distance education system, and that this was due to the fact that they could not hear the students at all and did not correct the incorrect pronunciation. Of course, it has different features due to the nature of art education. The aspect similar to that of foreign language education is that distance education is an indicator that every course cannot meet every need. In Table 6, the opinions about using technology in design courses are given by coding.

According to Table 6, students have remarkable views on the different applications that can be applied in the lessons. Thinking students such as $S_{3}, S_{6}$ and $S_{18}$ can be organized in a virtual exhibition during the classes, students who think like $\mathrm{S}_{5}, \mathrm{~S}_{11}$ and $\mathrm{S}_{20}$ can use different drawing applications such as 'Autodesk SketchBook' on their mobile phones, students who think like $S_{9}, S_{13}$ and $S_{22}$ are guided by the instructor in the lessons. Virtual trips to museums and historical monuments can be made, while students who think like $\mathrm{S}_{8}, \mathrm{~S}_{13}$ and $\mathrm{S}_{32}$ think that hobby studies can be done. When the detailed opinions of the students were examined, it was determined that they stated:

$\mathrm{S}_{6}$. The work we do in classes can be organized as an online exhibition for both classmates and other people to see. In addition, this exhibition will be a memory for us.

$\mathrm{S}_{10}$. Every student has a smart cell phone. Applications such as 'Autodesk SketchBook' to be installed on 
these phones can be used. Thanks to these programs, we do not spend money on the material and therefore it is more economical. We can upload these pictures directly to the distance education system without any extra action. It will be an easy and practical application. In this way, we can also do more original works. Because I do not have the ability with real material such as paper and pencil, I can behave more comfortably because I can make mistakes and delete them instantly without fear in this application.

Table 6. Opinions on the Different Applications That can be done in Distance Education in Art and Design Courses



In the information age we are in, it is inevitable to use technology, which is an integral part of every field, in art and design education. The acquisition of technology by the individual who makes artistic designs, the opportunity to do a lot of work in a short time, and to create original designs and compositions, and as a result of this, the artist is directed towards collaborative and collective work from individuality (Bequette \& Bequette, 2012). Therefore, it may be possible to eliminate the behaviors that have difficulties in fooling the student during the distance education process, even with a piece of technology. Therefore, as in face-to-face education, different applications of technology should be used in art activities during the distance education process.

$\mathrm{S}_{21}$. During the distance education process, we can visit the virtual gallery, museum and historical places that we can access from the internet under the guidance of our instructor. I am sure it will be a very interesting application. In this way, our general culture will also increase.

$\mathrm{S}_{32}$. Special designs can be made for the student. These designs can be works that consist of hobby works and which we can use in our daily life. This can provide both activity and psychological relief to evaluate these times.

Engaging students is a challenging task in face-to-face and distance learning environments. As students are physically separated from other students and instructors in distance education, it becomes more difficult to attract students' attention (Bolliger \& Halupa, 2018; Moore, Utschig et al., 2008). Therefore, different applications to be carried out in line with the education program will increase the students' interest in the lesson.

Table 7. Opinions on the Level of Preparation of the Educational Institution in the Emergency Online Transition to Distance Education

\begin{tabular}{|c|c|c|}
\hline Category & $\mathrm{f}$ & Codes \\
\hline \multirow{6}{*}{$\begin{array}{l}\text { A6 } \\
\text { Technological } \\
\text { infrastructure }\end{array}$} & 18 & It is inadequate \\
\hline & & $\left(\mathrm{S}_{2}, \mathrm{~S}_{3}, \mathrm{~S}_{5}, \mathrm{~S}_{9}, \mathrm{~S}_{11}, \mathrm{~S}_{12}, \mathrm{~S}_{16}, \mathrm{~S}_{17}, \mathrm{~S}_{18}, \mathrm{~S}_{19}, \mathrm{~S}_{20}, \mathrm{~S}_{24}\right.$ \\
\hline & & $\left.\mathrm{S}_{25}, \mathrm{~S}_{26,}, \mathrm{~S}_{29}, \mathrm{~S}_{30}, \mathrm{~S}_{34}, \mathrm{~S}_{39}\right)$ \\
\hline & 17 & Should be developed \\
\hline & & $\left(\mathrm{S}_{4}, \mathrm{~S}_{7}, \mathrm{~S}_{13}, \mathrm{~S}_{14}, \mathrm{~S}_{21}, \mathrm{~S}_{22}, \mathrm{~S}_{23}, \mathrm{~S}_{27}, \mathrm{~S}_{28}, \mathrm{~S}_{31}, \mathrm{~S}_{32}, \mathrm{~S}_{33}, \mathrm{~S}_{35}, \mathrm{~S}_{36}, \mathrm{~S}_{40}, \mathrm{~S}_{41}, \mathrm{~S}_{43}\right)$ \\
\hline & 10 & It's enough. ( $\left.\mathrm{S}_{1}, \mathrm{~S}_{6}, \mathrm{~S}_{8}, \mathrm{~S}_{10}, \mathrm{~S}_{15}, \mathrm{~S}_{37}, \mathrm{~S}_{38}, \mathrm{~S}_{42}, \mathrm{~S}_{44}, \mathrm{~S}_{45}\right)$ \\
\hline
\end{tabular}

When the opinions on the level of preparation of the educational institution in the emergency online transition to distance education are examined in Table 7 , it is seen that the opinion that it is not prepared to a large extent is dominant. They stated that students who think like $\mathrm{S}_{2}, \mathrm{~S}_{3}, \mathrm{~S}_{5}$ are not enough and live lessons (Synchronous and asynchronous) are not possible, only various resources and presentations are uploaded. Students such as $\mathrm{S}_{4}, \mathrm{~S}_{7}, \mathrm{~S}_{14}$ stated that the system is good, but various additions should be made to improve it. On the other hand, students who think like $\mathrm{S}_{1}$ and $\mathrm{S}_{6}$ stated that the system is sufficient. Examples of these views of students shaped in line with their expectations from the lessons are given below. 
$\mathrm{S}_{2}$. In face-to-face education, weekly lessons reach 3 hours, while in online education, students try to study only 30-40 minutes via voice recordings, PDFs and slides. This is not sufficient and efficient for students. While the written exams are held in the midterm exams and final exams under normal conditions and offer the opportunity to better evaluate student's knowledge, the exams in online education are made multiple choice from the system via computer and telephone. Since the infrastructure of the school is not prepared for this, there are many problems in the system while conducting the exam. Due to the density experienced in the system and the Internet etc. There are many students who have difficulties in completing their exams due to problems and who have difficulties in the meantime. In addition, the online examination system in online education is not sufficient to evaluate the student. Of course, we will survive this difficult process. But in this process, we think that most of the students will receive more efficient education if compulsory online education is made through a system where students can participate in the form of live broadcasting.

$\mathrm{S}_{18}$. Unfortunately, it is not enough. As students, we saw this on the first day of distance education exams. We have no lecturers who do live lessons. We have problems during the exam or downloading material. We have a system that collapses at the time of course selection, the infrastructure is not good, I hope it can be improved.

The results of the research carried out by Sivrikaya (2019) support these findings. According to the results of the research that the chemistry department students who conducted in Sivrikaya determined their views on distance education, it was determined that most of the students stated that they did not see the distance education infrastructure sufficient. In the study of Yilmaz and Güven (2015), it has been determined that technical infrastructure problems in distance education have negative views about distance education. The negative views of students about distance education of art and design lessons coincide with the findings of Y1lmaz and Güven.

$\mathrm{S}_{14}$. I did not have a great level of difficulty in taking the course contents or exams. The system did not experience any system crash at the time of any seriously improved exam, but there were minor problems from the internet connection or system. The opportunities for live lessons during the distance education are limited and it is quite suitable for cheating at the time of the exam. The technological infrastructure of the institution providing distance education allows us, but it can be improved further.

$\mathrm{S}_{22}$. The school cannot be said to have sufficient levels, but there are deficiencies as in every system. We can often have trouble even entering the site. A situation that is constantly causing errors. But there is this process until the past, of course, we can manage mistakes day by day, obviously, the mistakes have started to decrease.

$\mathrm{S}_{10}$. I was hesitant in our school because we were trying to enter at a normal time, we were trying repeatedly for many days to be able to upload homework. I did not experience any problems at the time of the exam, there was no problem in the operation of the courses, it is carried out very successfully.

$\mathrm{S}_{44}$. Before the exams, the system was constantly crashing. I do not think that the infrastructure is smooth, but I do not think that the pandemic process is sufficient since I did not have a problem during the exam week.

Which it is taking place in the Covid-19 and 2020 emerged in late 2019 on a global scale and the World Health Organization (WHO) by declared a pandemic in the face of disaster, as the world's Turkey also to be made with distance learning courses conducted face to face in university with March 23 decision it is given. All universities were not prepared for this process during the distance education process, which was passed in line with this mandatory decision. Therefore, it is quite natural to have deficiencies. The most important lesson given by the pandemic process is that all educational institutions should be prepared for similar situations that can be encountered by completing the deficiencies in distance education infrastructures.

\section{Discussion}

The results regarding the opinions obtained in this research, which aims to determine the opinions of undergraduate students regarding the art and design courses taught by distance education, are as follows. An important part of students stated that the transition to distance education is rapid and this situation is difficult due to the lack of experience of using the distance education system, but then they overcome this difficulty.

They also stated that they had difficulty in using the technology, their interest in the lesson decreased, they could not follow the subjects and this distance education became boring from time to time. When the literature is analyzed, it is revealed that students have negative attitudes and views towards distance education for similar reasons (Gillies, 2008; 
Karal, Çebi, \& Turgut, 2011; Doğan \& Tatık, 2015). On the other hand, students stated that the fact that distance education does not have a time and place limit, that they can reach more examples and resources due to their technological infrastructure, this situation increases their interest in the lesson, they can allocate more time to lessons, the subjects become more understandable and their responsibilities will increase by increasing their consciousness. These views are the same as those seen as advantages of distance education. According to the results of the voucher (2013), the use of web-based educational materials was found to be successful by students and faculty members. The data obtained from the researches of Fiş (2013) supports this result.

When the students' views on the weaknesses of distance education were examined, it was determined that the problems they faced in using and accessing technology were the weakest aspects of this process. Second, they pointed out that this situation, which does not provide the socialization environment in the classroom, is the weakest aspect of the process. On the other hand, they stated that students' distance education cannot motivate them sufficiently and it is boring. The results of the research that Sivrikaya (2019) examined the views of chemistry students on distance education support these findings. As a result of the research, students stated that only the theoretical part of chemistry education can be given by distance education. The students stated that laboratory studies cannot be carried out with distance education they need a safe laboratory for this application and they cannot perform their experiments at home. As some of the studies in art education will only be carried out in a workshop environment, it has been observed that the application dimensions of the courses are the biggest problem encountered in the distance education process in both fields. It is thought that art and design lessons cannot be taught completely in distance education because they are application-oriented. In arts education, the fact that the lecturer has a direct intervention in student work is not really desired (Yilmaz, 2007). This can often reduce the creativity and self-confidence of the student, so since the task of the art educator in the process is guiding, it can be argued that it will be sufficient to process this process with a small number of students in a practical way. Therefore, more course hours may be needed than other courses. It is emphasized in the studies that students have an unstable attitude towards distance education because they do not have sufficient knowledge and experience about distance education applications (Ateş \& Altun, 2008) and when the necessary arrangements are made in distance education programs, perceptions about distance education will change positively (Gillian \& Gillian, 2004). Therefore, some of the students who presented negative opinions in this research may be more positive after this experience and after the necessary infrastructure arrangements of universities. In addition, some studies have shown that factors such as voice, image, communication problems, low interaction, body language used by teachers and duration of lessons in distance education applications affect participants' perceptions of distance education (Koppelman \& Vranken, 2008; Marsh, Mitchell, \& Adamczyk, 2010); and in particular, it shows that simultaneous distance education practices are insufficient to meet the expectations of the participants (Delaney, Jacob, Iedema, Winters \& Barton, 2004). The perceptions of the participants, whose expectations cannot be met, are also negative. Thus, this affects the quality of education and training and causes the activity to fail. Therefore, first of all, people should have a positive perception towards distance education.

\section{Conclusion}

As a result of the research, it is also seen that undergraduate students think that distance education is very necessary. They stated that it enables all students to access education equally, advances in technology make it necessary to be used in education, digital resources reduce the cost of education, increase their responsibilities, and bring equality to education because it enables students of different levels to access information whenever they want. They also stated that their anxiety during the pandemic process reduced their art and design work during the distance education process. In the research, students have remarkable views on the different applications that can be applied in the courses of art and design. It was concluded that the students thought that the application works carried out during the lessons could be organized in a virtual exhibition, different drawing applications such as "Autodesk SketchBook" could be used on their mobile phones, virtual trips to museums and historical works could be conducted under the guidance of the instructor, and students could do hobby studies. Finally, when the opinions about the technological infrastructure of the institution providing education in the process of transition to distance education are examined, it is seen that the opinion that it is not prepared to a large extent is dominant. In addition, some students stated that the system is good, but various additions should be developed. There are students who state that the system is sufficient against this. The main reason for the negative views about distance education, which is mandatory in the pandemic process, may be that they experience a very rapid transition period without being informed before.

In the light of the findings, at the end of the pandemic process, the universities should be informed about the more active work of the 'Distance Education Centers' and the distance education activities. After these informations, it may be beneficial to carry out short-term distance education activities by taking technical problems under control, designing 
environments where lecturers and students are in constant contact, and instructors have an attitude that will increase their motivation.

\section{References}

Adams, A., \& Timmis, F. (2006). Students views of integrating web-based learning tecnology into the nursing cirriculum-a descriptive survey. Nurse Education in Practice, 6, 2-21. https://doi.org/10.1016/j.nepr.2005.05.005

Alsabawy, A. Y., Steel, C, A., \& Soor, J. (2016). Determinants of perceived usefulness of e-learning systems. Computers in Human Behavior, 64, 843-858. https://doi.10.1016/j.chb.2016.07.065

Andrade, M. S. (2015). Teaching online: A theory-based approach to student success. Journal of Education and Training Studies, 3(5), 1-9. https://doi.org/10.11114/jets.v3i5.904

Aparicio, M., Bacao, F., \& Oliveira, T. (2016). Cultural impacts on e-learning systems' success. Internet and Higher Education, 31, 58-70. https://doi.org/10.17718/tojde.690385

Ateş, A., \& Altun, E. (2008). Bilgisayar öğretmeni adaylarının uzaktan eğitime yönelik tutumlarının çeşitli değişkenler açısından incelenmesi. [Investigating preservice computer teachers' attitudes towards distance learning regarding various variables]. Gazi Eğitim Fakültesi Dergisi, 28(3), 125-145. https://doi.org/10.17556/erziefd.305902

Babelan, A. Z., Ghhaderi, E., \& Moenikia, M. (2011). Attitudes of university applicant's toward distance education. Procedia Social and Behavioral Sciences, 30, 1926-1929. https://doi.org/10.1016/j.sbspro.2011.10.374

Bağrıçık, A. Y. (2019). Distance and face-to-face students' perceptions towards distance education: a comparative metaphorical study. Turkish Online Journal of Distance Education, 20(1), 191-207. https://doi.org/10.17718/tojde.522705

Bağraçık, A. Y., \& Banyard, P. (2020). Engagement in distance education settings: A trend analysis. Turkish Online Journal of Distance Education, 20(1), 101-112. https://doi.org/10.17718/tojde.690362

Baltac1, A. (2019). Sosyal sistem kuramı ve eğitim örgütlerine etkileri. [Social system theory and its effects on educational organizations]. Medeniyet Araştırmaları Dergisi, 3(1), 1-19.

Bequette, J. W., \& Bequette, M. B. (2012). A place for art and design education in the stem conversation. Art Education, 65(2), 40-47. https://doi.org/10.1080/00043125.2012.11519167

Bernat, F., \& Frailing, K. (2015). Perfecting lessons learned for criminal justice online graduate education: Reflection, integration, and application. Journal of Criminal Justice Education, 26(3), 330-353. https://doi.org/10.1080/10511253.2015.1036090

Bhagati, K. K., Wu, L. Y., \& Chang, C. Y. (2016). Development and validation of the perception of students towards online learning (POSTOL). Journal of Education Technology \& Society, 19(1), 350-359.

Bilgiç, H. G., \& Tuzun, H. (2020). Issues and challenges with web-based distance education programs in Turkish higher education institutes. Turkish Online Journal of Distance Education, 21(1), 143-164. https://doi.org/10.17718/tojde.690385

Bolliger, D. U., \& Halupa, C. (2018). Online student perceptions of engagement, transactional distance, and outcomes. Distance Education, 1(18), 299-316. https://doi.org/10.1080/01587919.2018.1476845

Carpenter, S., Reddix, R., \& Martin, D. (2016). Pills, thrills, and pharmacology drills! Strategies to increase student retention in an entry-level nursing pharmacology course. Teaching and Learning in Nursing, 11(4), 179-183. https://doi.org/10.1016/j.teln.2016.04.002

Chaudry, M. A., \& Rahman, F. (2010). A critical review of instructional design process of distance learning system. Turkish Online Journal of Distance Education-TOJDE, 11(3).

Council of Higher Education. (2020). Procedures and principles regarding distance education in higher education

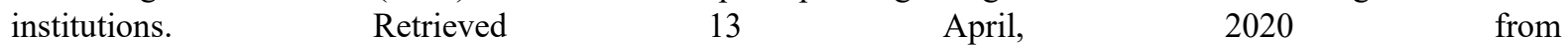
https://www.yok.gov.tr/Sayfalar/Haberler/2020/universitelerde-uygulanacak-uzaktan-egitime-iliskin-aciklama.a spx

Delaney, G., Jacob, S., Iedema, R., Winters, M., \& Barton, M. (2004). Comparison of face-to-face and video conferenced multidisciplinary clinical meetings. Australasian Radiology, 48(4), 487-492. 
https://doi.org/10.1111/j.1440-1673.2004.01349

Delen, E., Liew, J., \& Willson, V. (2014). Effects of interactivity and instructional scaffolding on learning: Self-regulation in online video-based environments. Computers \& Education, 78, 312-320. https://doi.org/10.1016/j.compedu.2014.06.018

Dimri, K. A., \& Chaturvedi, A. (2009). Analysis with learner input of student support services in Indian. The Asian Society of Open and Distance Education, 7(2), 4-16.

Doğan, S., \& Tatık, R. Ş. (2015). Evaluation of distance education program in Marmara University according to the views of students. Route Educational and Social Science Journal, 2(1), 247-261. https://doi.org/10.17121/ressjournal.187

Elitaş, T. (2017). New communication technologies in distance education license period: Atatürk University distance education center. [Unpublished doctoral dissertation], Marmara University.

Ergün, M. (1994). Eğitim sosyolojisi. [Education sociology]. Ocak Yayınları.

Fedyinch, L., Bradley, K. S., \& Bradley, J. (2015). Graduate students's perception of line learning. Research in Higher Education Journal, 27(2), 1-13.

Fiş, E. S. (2013). Web tabanlı uzaktan eğitimde biyoloji dersi için ders materyali tasarımı: kriterler, uygulama ve değerlendirme [Course material design for biology course in web based distance education: criteria, application and evaluation]. Journal of Instructional Technologies \& Teacher Education, 2(1), 86-111.

Gillian, F., \& Gillian, P. (2004, September 16-18). Mind the gap: Students' expectations and perceptions of induction to distance learning in higher education. British Educational Research Association (BERA) Annual Conference, UMIST, Manchester, UK

Gillies, D. (2008). Student perspectives on video-conferencing in teacher education at a distance. Distance Education, 29(1), 107-118. https:// doi.org/10.1080/01587910802004878

Halter, M., Kleiner, C., \& Hess, R. F. (2006). The experience of nursing students in an online doctoral program in nursing: A phenomenological study. International Journal of Nursing Studies, 43(1), 99-105. https://doi.org/10.1016/j.ijnurstu.2005.03.001

Islam, A. K. M. N. (2016). E-learning system use and its outcomes: Moderating role of perceived compatibility. Telematics and Informatics, 33, 48-55. https:// doi.org/10.1016/j.tele.2015.06.010

Işman, A. (2008). Uzaktan eğitim. [Distance education]. Pegem.

Karal, H., Çebi, A., \& Turgut, Y. E. (2011). Perceptions of students who take synchronous courses through video conferencing about distance education. The Turkish Online Journal of Educational Technology-TOJET, 10(4), 276-293.

Kaya, Z. (2002). Uzaktan eğitim. [Distance education]. Pegem.

Ma, J., Han, X., Yang, J., \& Cheng, J. (2015). Examining the necessary condition for engagement in an online learning environment based on learning analytics approach: The role of the instructor. The Internet and Higher Education, 24, 26-34. https://doi.org/10.1016/j.iheduc.2014.09.005

Maisonneuve, H., Chambe, J., Lorenzo, M., \& Pelaccia, T. (2015). How do general practice residents use social networking sites in asynchronous distance learning?. BMC Medical Education, 15(1), 154. https://doi.org/10.1186/s12909-015-0435-x

Marsh, B., Mitchell, N., \& Adamczyk, P. (2010). Interactive video technology: Enhancing Professional learning in initial teacher education. Computer \& Education, 54(3), 742-748. https://doi.org/10.1016/j.compedu.2009.09.011

Martin, F., \& Bolliger, D. U. (2018). Engagement matters: Student perceptions on the importance of engagement strategies in the online learning environment. Online Learning, 22(1), 205-222. https://doi.org/10.24059/olj.v22i1.1092

Miles, M, B., \& Huberman, A. M. (1994). Qualitative data analysis: An expanded Sourcebook (2nd ed.). Thousand Oaks, Sage.

Moore II, E., Utschig, T. T., Haas, K. A., Klein, B., Yoder, P. D., Zhang, Y., \& Hayes, M. H. (2008). Tablet PC technology for the enhancement of synchronous distributed education. IEEE Transactions on Learning 
Technologies, 1(2), 105-116. https://doi.org/10.1109/TLT.2008.19

O'Lawrence, H. (2006). The influences of distance learning on adult learners. Techniques: Connecting Education \& Careers, 81(5), 47-49.

Sarıtas, M. (2009). Uzaktan eğitim. [Distance education.] In M.Sarıtas (Eds.), Öğretim teknolojileri ve materyal tasarımı [Instructional technologies and material design] (pp.55-102). Pegem.

Sivrikaya, Ö. S. (2019). Chemistry students' opinions about taking chemistry education as distance education. European Journal of Open Education and E-learning Studies, 4(2), 35-45. https://doi.org/10.5281/zenodo.3592897

Snodgrass, S. (2011). Wiki activities in blended learning for health professional students: Enhancing critical thinking and clinical reasoning skills. Australasian Journal of Educational Technology, 27(4). https://doi.org/10.14742/ajet.938

Tomas, L., Lasen, M., Field, E., \& Skamp, K. (2015). Promoting online students' engagement and learning in science and sustainability preservice teacher education. Australian Journal of Teacher Education, 40(11), 79-107. https://doi.org/ajte.2015v40n11.5

Toven, L. B., Rhoads, R. A., \& Lozano, J. B. (2015). Virtually unlimited classrooms: Pedagogical practices in massive open online courses. The Internet And Higher Education, 24, 1-12. https://doi.org/10.1016/j.iheduc.2014.07.001

Ünalan, H. T. (2016). Eğitim fakültesi güzel sanatlar eğitimi bölümlerinde internet destekli öğrenme ortamlarının oluşturulması. [Creating internet supported learning environments in the faculty of education, in fine arts education departments]. Açıöğretim Uygulamaları ve Araştırmaları Dergisi, 2(1), 130-147.

Ünsal, H. (2007). Harmanlanmış öğrenme etkinliğinin çoklu düzeyde değerlendirilmesi. [Evaluation of blended learning acticity on multiple levels], [Unpublished doctoral dissertation], Gazi University.

Ward, M. E., Peters, G., \& Shelley, K. (2010). Student and faculty perceptions of the quality of line learning experiences. The International Review of Research in Open and Distributed Learning, 11(3), 57-77. https://doi.org/10.19173/irrodl.v11i3.867

Yıldırım, A., \& Şimşek, H. (2003). Sosyal bilimlerde nitel araştırma yöntemleri, [Qualitative research methods in the social sciences]. Seçkin Yayıncılık.

Y1ldı, M., \& Erdem, M. (2018). An investigation on instructors' knowledge, belief and practices towards distance education. Malaysian Online Journal of Educational Technology, 6(2), 1-20. https://doi.org/10.17220/mojet.2018.04.001

Yılmaz, K, G., \& Guven, B. (2015). Öğretmen adaylarının uzaktan eğitime yönelik algılarının metaforlar yoluyla belirlenmesi. [Determining the teacher candidates'perceptions on distance education by metaphors]. Turkish Journal of Computer and Mathematics Education, 6(2), 299-322. https://doi.10.16949/turcomat.75936

Yılmaz, M. (2007). Görsel sanatlar eğitiminde işbirlikli öğrenme. [Cooperative learning in visual arts education]. Kastamonu Ĕgitim Dergisi, 15(2), 747-756.

Yu, S., \& Yang, K. F. (2006). Attitudes toward web-based distance learning among public health nurses in Taiwan: A questionnaire survey. International Journal of Nursing Studies, 43, 767-774. https://doi.org/10.1016/j.ijnurstu.2005.09.005

Zor, A. (2008). Yapılandırmacı yaklaşıma göre web tabanlı bilgisayar destekli sanat eğitimi. [Web based computer aided art education in accordance with structural approach], [Unpublished doctoral dissertation]. Gazi University. 